\title{
O(s) Prémio(s) da Crítica 2005
}

\section{Paulo Eduardo Carvalho}

Não obstante as cada vez maiores dificuldades envolvidas na realização destas edições dos novos Prémios da Crítica, continuamos a acreditar na sua pertinência e validade. Não concordamos com a sugestão, já avançada por alguns, de que a atribuição anual de tão modestas distinções possa contribuir para a ilusão de se estar no mais perfeito dos mundos. Bem pelo contrário: o reconhecimento crítico e público de que a criação teatral portuguesa continua a ser merecedora de louvor deve funcionar também como a denúncia positiva do trabalho verdadeiramente extraordinário desenvolvido pelos nossos criadores, sobretudo no contexto de um sistema frágil, indefinido e repetidamente sujeito às mais casuisticas das decisões da tutela responsável. Acrescentaria ainda que a importância destas distinções concedidas pela APCT se impõe como tanto maior quanto assistimos ao silencioso desaparecimento de outros prémios, como parece ter acontecido, sem quaisquer explicações públicas, com os Prémios Almada e Revelação Ribeiro da Fonte, de iniciativa ministerial, e o Prémio ACARTE, da Fundação Calouste Gulbenkian. Congratulamo-nos, contudo, por este ter sido o ano em que o Prémio Nobel da Literatura - e, mais recentemente, também o Prémio Europa de Teatro, de que se dá conta mais adiante, nas páginas desta revista - terem cabido a Harold Pinter, e, por entre nós, o Prémio Pessoa, justa e merecidamente, ter por fim distinguido um criador teatral, Luis Miguel Cintra.

Tal como temos repetidamente explicado nas edições anteriores, a dificuldade de dar conta, de uma forma que desejariamos exaustiva e abrangente, das experiências cada vez mais atomizadas e amplamente distribuídas pelo território nacional, frequentemente sujeitas a periodos de apresentação consideravelmente curtos, levou-nos a rejeitar a mais tradicional distinção por categorias, optando por um conjunto menos abundante, mas nem por isso menos atento e empenhado, de prémios. Assim, e de acordo com o regulamento aprovado no início do ano de 2003, o Prémio da Crítica da APCT destina-se a distinguir "uma invulgar contribuição para o panorama artístico nacional" no domínio das artes performativas, contemplando ainda a possibilidade de atribuição de três Menções Especiais, sujeitas ao mesmo tipo de consideração. Nas duas últimas edições, o Prémio da Crítica foi atribuido à tradutora e dramaturgista Vera San Payo de Lemos e ao espectáculo Para além do Tejo, uma criação de Miguel Seabra. Foram também já contemplados com Menções Especiais: o projecto "Percursos", nas pessoas dos seus coordenadores, Madalena Victorino e Giacomo Scalisi; o sonoplasta e desenhador de som Francisco Leal; e os espectáculos: Circo, escrito e encenado por Carlos J. Pessoa; O fazedor de teatro, com encenação de Joaquim Benite; Luz/Interior, um projecto de Rita Só; e ainda o espectáculo A cabra, ou quem é Silvia?, com encenação de Álvaro Correia.

Nesta terceira edição, decidiu um júri constituído por João Carneiro, Maria Helena Serôdio, Sebastiana Fadda e por mim próprio, atribuir o Prémio da Crítica 2005 exaequo aos espectáculos UBUs e Um homem é um homem, produzidos respectivamente pelo Teatro Nacional S. João e pelo Teatro da Cornucópia, nas pessoas dos seus encenadores, Ricardo Pais e Luís Miguel Cintra. As Menções Especiais foram concedidas ao dramaturgo Miguel Castro Caldas, pela criação de textos como, entre outros, Nuncaterra em vez de Peter Pan, ao espectáculo Serviço d'amores, uma produção do Teatro Nacional D. Maria II, com a colaboração de As Boas Raparigas, na pessoa da sua encenadora, Maria Emília Correia, e, por último, ao elenco do espectáculo Luz na cidade, encenado por João Lourenço para o Novo Grupo/Teatro Aberto, nas pessoas dos actores Marco Delgado, Nuno Gil, Rui Mendes e São José Correia.

Tal como já aconteceu nas duas edições anteriores e esta vem sendo, pensamos, a generosidade maior destes prémios - acompanhámos a cerimónia pública de entrega dos nossos troféus com a mais discursiva expressão dos méritos diversos reconhecidos às realidades distinguidas. Unanimemente subscritas por todos os membros do júri, as intervenções que agora integram este dossiê resultam das abordagens pessoais de cada um dos intervenientes. Uma vez que algumas das realidades distinguidas tinham sido já contempladas nas páginas desta revista, parte do discurso então produzido surge, de alguma forma, recuperado nos textos que se seguem.

Resta-nos agradecer a contribuição dos nossos associados, que nos fizeram atempadamente chegar as suas nomeações, e a presença de todos aqueles que estiveram connosco no passado dia 27 de Março, na Sala dos Espelhos do Palácio Foz, onde se realizou a cerimónia de entrega dos prémios, devido à colaboração generosa dos responsáveis pela gestão daquele espaço, nas pessoas do Dr. João Palha e da Dra. Anabela Martins Baptista. Uma

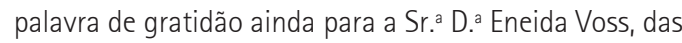
Relações Públicas, que nos ajudou em algumas das formalidades. Aproveitamos também para assinalar com reconhecimento a presença do Dr. Orlando Farinha, em representação do Instituto das Artes. 


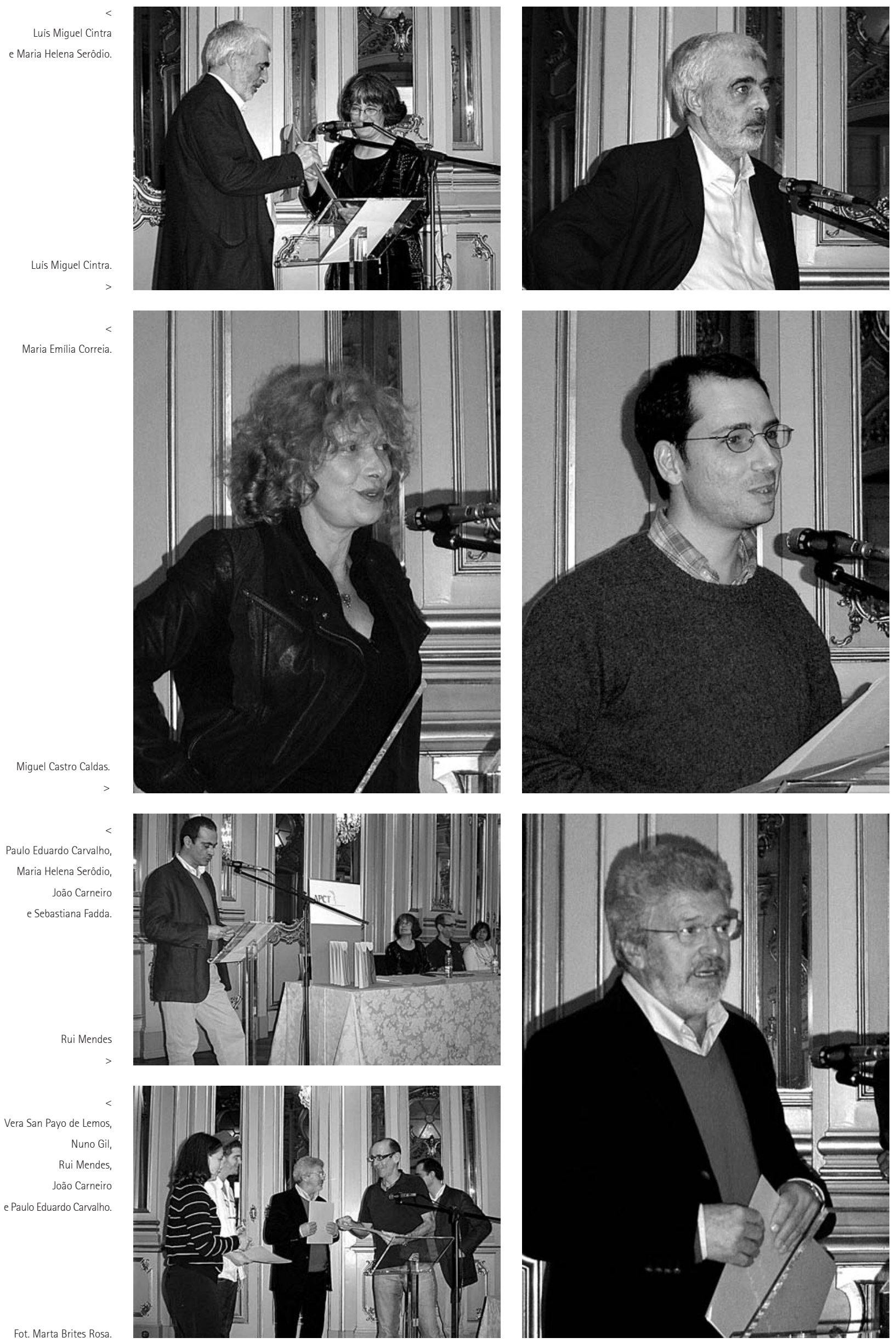

